\title{
Inhibition of Lactophage Activity by Quinolinilporphyrin and Its Zinc Compex
}

\author{
NATALIA VODZINSKA ${ }^{1 *}$, BORIS GALKIN ${ }^{1}$, YURIY ISHKOV ${ }^{1}$, ANNA KIRICHENKO $^{1}$, \\ ALEXANDRA KONDRATYUK ${ }^{2}$ and TETIANA FILIPOVA ${ }^{2}$ \\ ${ }^{1}$ Biotechnological Scientific-Educational Centre of I.I. Mechnikov Odessa National University, Odessa, Ukraine \\ ${ }^{2}$ Department of Microbiology and Virology, I.I. Mechnikov Odessa National University, Odessa, Ukraine
}

Received 28 March 2011, revised 26 June 2011, accepted 5 July 2011

\begin{abstract}
The influence of free base of quinolinilporphyrin and its Zn complex on infectivity of lactophages E3, E5 and E17 has been studied. The results of our investigations show that inhibition of lactophage activity by $\mathrm{Zn}$ complex of quinolinilporphyrin at concentration $10 \mu \mathrm{M}$ and $20 \mu \mathrm{M}$ was in the range $53-62 \%$ and $65-85 \%$, respectively. The presence of this porphyrin in nutrient medium prevents the propagation of bacteriophage infection in Lactococcus lactis, but does not affect the phage adsorption process. The free base of quinolinilporphyrin slightly inhibits the activity of lactophages.
\end{abstract}

Ke y w ord s: Lactococcus lactis, lactophage, quinolinilporphyrin

\section{Introduction}

Various lactic acid bacteria have been used for centuries in the preservation and production of fermented foods and feeds of plant and animal origins. One of the most critical problems in these processes is the contamination of the starters by bacteriophages that cause bacterial lysis and leads to failed or slow fermentation, decrease in acid production, reduction of milk products quality, e.g. taste and texture (Coffey and Ross, 2002), which all result in profound economical losses.

Recognition of the phage problem in the dairy industry led to the design and application of a variety of practical measures for its alleviation, such as direct inoculation of the starters in closed fermentation vats, use of antiphage media for starter propagation, rotation of starter cultures, application of genetic techniques to improve the phage-resistance of starter cultures (however, European legislation requires the labelling such of starters as GMO that were modified by self-cloning and thus contain only species-specific DNA) (Kutter and Sulakvelidze, 2005).

Porphyrins are one of the challenging compounds for infectious disease treatment (Nitzan et al., 1994). Nowadays they are widely used in anticancer photodynamic therapy. This method is based on the use of a photosensitizer, which after light exposure can cause different derangements of cell structures. It was shown that porphyrins have good antibacterial effect even without activation by light (Philippova et al., 2003). Porphyrins and their derivatives appear to be effective virucidal agents in vitro (Cowsert, 1994; Grandadam et al., 1995). Most of the work on viruses in vitro has been oriented to the use for sterilization of blood or blood products (North et al., 1993). In some works bacteriophages were used as a model of viruses to study mechanisms of porphyrin action (Zupan et al., 2004; Vodzinska et al., 2008). These compounds showed good effect as inhibitors of phytoviral infection in plant tissue culture and in vivo (Krulko et al., 2008; 2009).

The aim of this work was to test the ability of new synthetic porphyrins to inhibit the activity of lactophages, namely phage E3, E5 and E17 of Lactococus lactis, without activation by light.

\section{Experemental}

\section{Materials and Methods}

Bacterial and phage strains. Lactococcus lactis subsp. lactis 502 and bacteriophages E3, E5 and E17 were obtained from the collection of Belarusian State Technological University. Bacterial strains were grown and maintained at $30^{\circ} \mathrm{C}$ in M17 medium (Merck) with the following composition (Terzaghi and Sandine, 1975) (g/l): peptone from soymeal (5.0), peptone from

\footnotetext{
* Corresponding author: N. Vodzinska, Biotechnological Scientific-Educational Centre of I.I. Mechnikov Odessa National University; str. Dovzhenko 7a, 65058 Odessa, Ukraine; e-mail: nsvod@ukr.net
} 

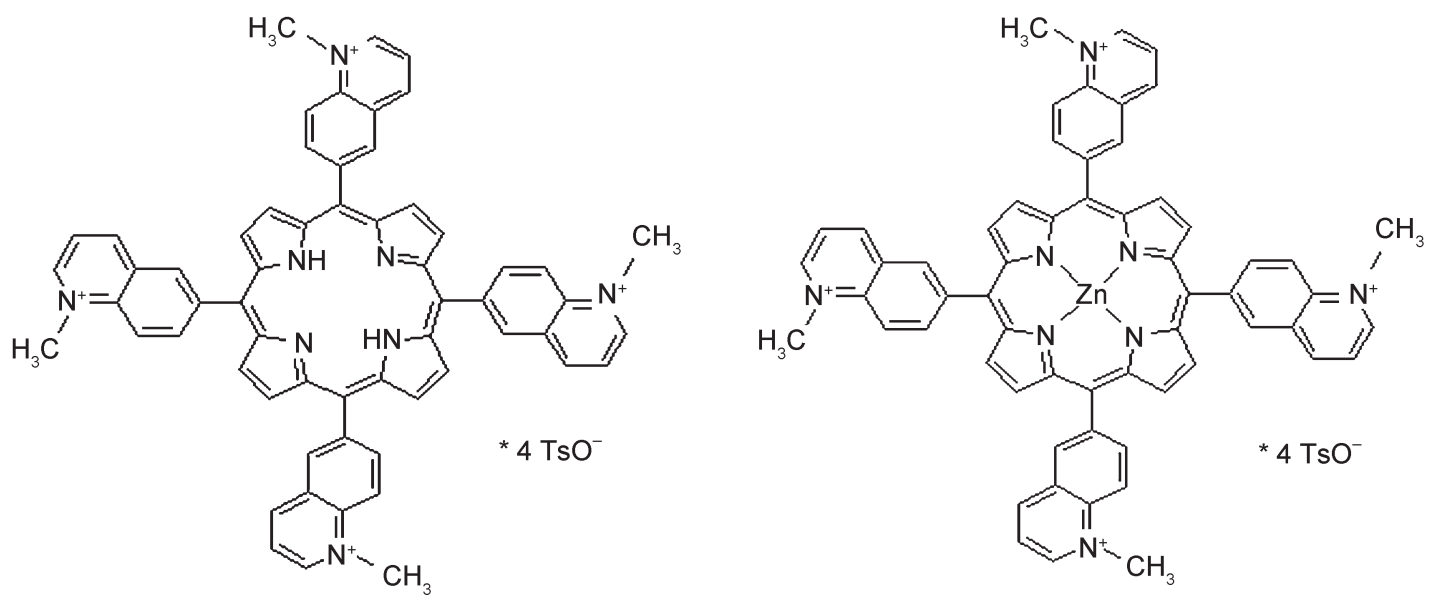

Fig. 1. Quinolinilporphyrin and its zinc complex structure.

meat (2.5), peptone from casein (2.5), yeast extract (2.5), meat extract (5.0), lactose monohydrate (5.0), ascorbic acid (0.5), sodium $\beta$-glycerophosphate (19.0), magnesium sulfate $(0.25)$, supplemented with $0.5 \%$ glucose. When necessary, the medium was solidified with agar-agar ( $5 \mathrm{~g} / \mathrm{l}$ for top agar, $10 \mathrm{~g} / \mathrm{l}$ for bottom agar). Preparation of phage stocks was carried out in liquid medium $\mathrm{M} 17$ in the presence of $5 \mathrm{mM} \mathrm{CaCl}_{2}$.

Chemicals. The antiphage activity of free base of quinolinilporphyrin (TQP) and its complex with $\mathrm{Zn}$ (Zn(II)TQP) (Fig. 1), synthesized in PLMS-5 of Odessa National University named after I.I. Mechnikov, has been studied. They were stored at $4^{\circ} \mathrm{C}$ in powder form or as a stock solution in distilled water.

Plaque reduction assay. The direct action of porphyrins on the viral particles was studied by using the plaque reduction assay (Ramezani et al., 2008). Bacteriophage was incubated with compound in medium M17 24 hours at $4^{\circ} \mathrm{C}$, then plated using standard double-layer method and incubated at $30^{\circ} \mathrm{C}$ overnight. The antiphage activity was expressed in percents of inactivation, which were calculated by means of formula: $\mathrm{A}=\left(1-\mathrm{N}_{\mathrm{s}} / \mathrm{N}_{\mathrm{k}}\right) \times 100 \%$, where $\mathrm{N}_{\mathrm{s}}$ is a number of plaque forming units in test sample, $\mathrm{N}_{\mathrm{k}}$ is the number of plaque forming units in the control.

Inhibition of bacteriophage infection in the liquid medium. To check the influence of porphyrin on bacteriophage infection in L. lactis bacterial cells $\left(1 \times 10^{3} \mathrm{cfu} \mathrm{cm}^{-3}\right)$ and bacteriophage $\left(5 \times 10^{4} \mathrm{pfu} \mathrm{cm}^{-3}\right)$ were simultaneously added to test tubes which contained liquid medium M17 with different concentrations of compound. Test tubes without the studied compounds were used for determination of normal course of phage infection. Test tubes to which only L. lactis was added were used as a control. After 24 hours of incubation the optical density of samples was measured and compared with that in the control. Optical density measurements were made on spectrophotometer "Spekol-10" at $\lambda=540 \mathrm{~nm}$ (Philippova at al., 2003).
Inhibition of bacteriophage adsorption. To study the influence of porphyrins on the phage adsorption process the bacterium was incubated with bacteriophage in the presence of the compounds at $30^{\circ} \mathrm{C}$ for $15 \mathrm{~min}$. Test tubes without compounds were used as control for determination of phage adsorption inhibition. After 15 minutes the incubation was stopped by diluting (1:100) in normal saline solution and the mixture was centrifuged for $5 \mathrm{~min} 5000 \mathrm{x}$ g. The supernatants were assayed for non-adsorbed phages by standard double-layer method, and the results compared with the titer of a control without bacterial cells. Phage adsorption was calculated as follows: Percentage adsorption $=($ control titre - residual titre $) /$ control titre $\times 100 \%$.

\section{Results and Discussion}

The main property for all antiviral agents is the absence of toxic effect on a host-cell. So for the start the influence of studied porphyrins on the growth of Lactococcus lactis culture has been checked. The porphyrin concentrations which not inhibit bacterial growth have been chosen. For both compounds those were concentrations $0.1 \mu \mathrm{M}, 1 \mu \mathrm{M}, 10 \mu \mathrm{M}, 20 \mu \mathrm{M}$. To determinate direct porphyrin action on the viral particles the bacteriophages were incubated with these compounds and then plated by the standard double-layer method.

The results show that $\mathrm{Zn}$ complex of quinolinilporphyrin was the most effective against all studied bacteriophages. Maximal antiphage activity was observed in the presence of $20 \mu \mathrm{M}$ of this compound. The inhibition of phage infectivity was in the range $65-85 \%$. Bacteriophage $\mathrm{E} 3$ was the most sensitive to this porphyrin concentration. The antiphage effect of $\mathrm{Zn}$ complex at the concentration of $10 \mu \mathrm{M}$ was equal to $53 \%$ for E5 and reached $62 \%$ for E3 and E17 bacteriophages. Other concentrations of this porphyrin decreased bacteriophage activity by $3-25 \%$. The inhibition of lactophage 


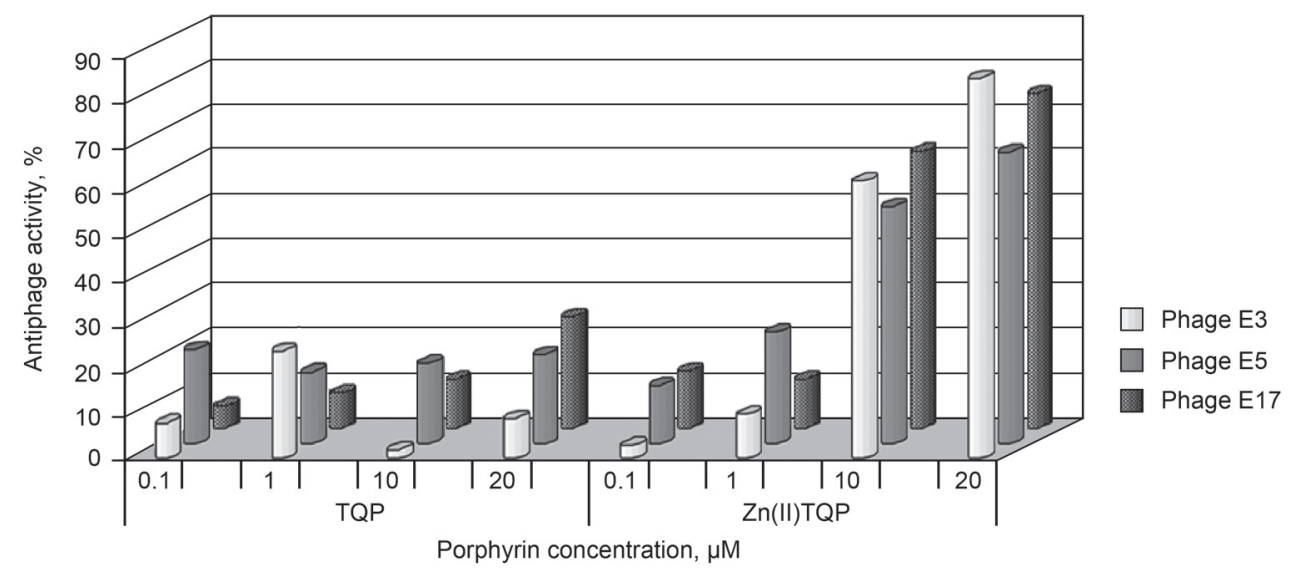

Fig. 2. Inhibition of bacteriophage activity in plaque reduction assay.

activity by free base of quinolinilporphyrin was in the $2-25 \%$ range (Fig. 2).

Data obtained in the experiments with liquid medium demonstrate similarity to data obtained in the plaque reduction assay. The results of these experiments show that the presence of quinolinilporphyrin $\mathrm{Zn}$ complex in the nutrient medium prevents the propagation of bacteriophage infection in L. lactis.

Growth intensity of this bacterium in the presence of bacteriophage E3 and concentrations $10 \mu \mathrm{M}$ and $20 \mu \mathrm{M}$ of quinolinilporphyrin $\mathrm{Zn}$ complex reached up $111 \%$, as compared with control. These concentrations of compound were also effective against bacteriophages E5 and E17, wherein the bacterium growth intensity reached up 104\% and 102\%, respectively. The presence of $1 \mu \mathrm{M}$ of this compound in the nutrient medium also inhibited phage activity and bacterial growth was in the range $43-82 \%$. The minimal concentration of this porphyrin wasn't effective in prevention of bacteriophage infection (Tabele I).

Table I

Lactococcus lactis subsp. lactis 502 growth intensity in presence of bacteriophages and different concentrations of porphyrins, $\mathrm{OD}_{540} \times 10^{-3}$

\begin{tabular}{|l|r|c|c|c|}
\hline \multicolumn{2}{|l|}{ Quinolinilporphyrins } & E3 & E5 & E17 \\
\hline \multirow{4}{*}{ TQP } & $0.1 \mu \mathrm{M}$ & $87 \pm 24$ & $351 \pm 88$ & $93 \pm 7$ \\
\cline { 2 - 5 } & $1 \mu \mathrm{M}$ & $65 \pm 3$ & $298 \pm 66$ & $59 \pm 3$ \\
\cline { 2 - 5 } & $10 \mu \mathrm{M}$ & $56 \pm 8$ & $261 \pm 57$ & $77 \pm 20$ \\
\cline { 2 - 5 } & $20 \mu \mathrm{M}$ & $236 \pm 49$ & $707 \pm 93$ & $292 \pm 5$ \\
\hline \multirow{4}{*}{ Zn(II)TQP } & $0.1 \mu \mathrm{M}$ & $77 \pm 7$ & $391 \pm 52$ & $88 \pm 6$ \\
\cline { 2 - 5 } & $1 \mu \mathrm{M}$ & $818 \pm 128$ & $1945 \pm 197$ & $805 \pm 104$ \\
\cline { 2 - 5 } & $10 \mu \mathrm{M}$ & $1918 \pm 69$ & $2466 \pm 106$ & $1913 \pm 53$ \\
\cline { 2 - 5 } & $20 \mu \mathrm{M}$ & $1955 \pm 21$ & $1587 \pm 94$ & $1925 \pm 29$ \\
\hline $\mathrm{C}_{1}$ & $105 \pm 13$ & $295 \pm 53$ & $71 \pm 6$ \\
\hline $\mathrm{C}_{2}$ & $1757 \pm 93$ & $2364 \pm 57$ & $1890 \pm 32$ \\
\hline
\end{tabular}

Note: $C_{1}-L$. lactis + bacteriophage in medium without porphyrins, $\mathrm{C}_{2}-$ L. lactis without addition of bacteriophages
The free base of quinolinilporphyrin slightly inhibited the activity of lactophages only in its maximal concentration. Other concentrations of this compound didn't affect the phage infection course in L. lactis.

Taking into consideration that the studied compounds have antiviral effect it was reasonable to check their ability to affect the initial stage of infection. The influence of porphyrin on viral adsorption was studied by determination of unadsorbed phage.

The obtained results show that though quinolinilporphyrin Zn complex had a good effect in lactococcal infection inhibition it didn't influence the phage adsorption process. The free base of quinolinilporphyrin showed only slight inhibition of lactophage adsorption in concentration $10 \mu \mathrm{M}$ and $21-37 \%$ at $20 \mu \mathrm{M}$. (Table II). Perhaps this delay of bacteriophage adsorption can be mediated by aggregation with viral peptides. At the same time the $\mathrm{Zn}$ complex may have another mechanism of antiphage action. The target of this porphyrin action can be bacteriophage DNA. It has been described that porphyrins can bind to DNA by intercalation between base pairs or external binding in a groove (Pasternack et al., 1983). Studies of cationic

Table II

Effect of porphyrins on lactophages adsorption to Lactococcus lactis subsp. lactis 502

\begin{tabular}{|c|c|c|c|c|}
\hline \multirow{2}{*}{\multicolumn{2}{|c|}{ Quinolinilporphyrins }} & \multicolumn{3}{|c|}{ Phage adsorption, \% } \\
\hline & & \multirow{2}{*}{$\begin{array}{c}\text { E17 } \\
91 \pm 2\end{array}$} & \multirow{2}{*}{$\begin{array}{c}\text { E17 } \\
96 \pm 3\end{array}$} & \multirow{2}{*}{$\begin{array}{c}\text { E17 } \\
77 \pm 3\end{array}$} \\
\hline TQP & $0.1 \mu \mathrm{M}$ & & & \\
\hline & $1 \mu \mathrm{M}$ & $88 \pm 4$ & $95 \pm 1$ & $84 \pm 4$ \\
\hline & $10 \mu \mathrm{M}$ & $69 \pm 1$ & $72 \pm 3$ & $68 \pm 1$ \\
\hline & $20 \mu \mathrm{M}$ & $59 \pm 2$ & $67 \pm 2$ & $68 \pm 3$ \\
\hline \multirow[t]{4}{*}{$\mathrm{Zn}(\mathrm{II}) \mathrm{TQP}$} & $0.1 \mu \mathrm{M}$ & $91 \pm 2$ & $97 \pm 1$ & $78 \pm 2$ \\
\hline & $1 \mu \mathrm{M}$ & $92 \pm 3$ & $96 \pm 2$ & $85 \pm 4$ \\
\hline & $10 \mu \mathrm{M}$ & $90 \pm 1$ & $96 \pm 4$ & $83 \pm 3$ \\
\hline & $20 \mu \mathrm{M}$ & $90 \pm 3$ & $95 \pm 1$ & $85 \pm 1$ \\
\hline \multicolumn{2}{|l|}{ Control } & $94 \pm 2$ & $97 \pm 2$ & $86 \pm 3$ \\
\hline
\end{tabular}


porphyrin binding to the isolated and encapsidated DNA of T7 bacteriophage have shown that the presence of the protein capsid in the phage particle does not exclude the interaction between porphyrin and intraphage DNA (Zupan et al., 2004). Besides, Duwat et al. (2001) have patented a process for preparing lactic acid bacteria starter cultures which comprises culturing bacteria under aeration and in an appropriate nutrient medium in the presence of some porphyrins. They suggest that the molecule of porphyrin can protect cells from oxidative damage. Their studies show that respiration conditions result in improved growth and a remarkable increase in long-term survival compared to growth under conventional fermentation conditions.

Thus, the results of our investigation show that the $\mathrm{Zn}$ complex of quinolinilporphyrin can be considered a perspective antiphage agent and in taking into account the preceding information additional studies can be used as a medium component for starters in dairy industry.

\section{Literature}

Coffey A. and R.P. Ross. 2002. Bacteriophage-resistance systems in dairy starter strains: molecular analysis to application. Antonie van Leeuwenhoek 82: 303-321.

Cowsert L.M. 1994. Treatment of papillomavirus infections: recent practice and future approaches. Intervirology 37: 226-230.

Duwat P., S. Sourice, B. Cesselin, G. Lamberet, K. Vido, P. Gaudu, Y. Le Loir, F. Violet, P. Loubière and A. Gruss. 2001. Respiration capacity of the fermenting bacterium Lactococcus lactis and its positive effects on growth and survival. Journal of Bacteriology. 183: 4509-4516.
Grandadam M., D. Ingrand and J.M. Huraux. 1995. Photodynamic inactivation of cell-free HIV strains by a red absorbing chlorin-type photosensitizer. Journal of Photochemistry and Photobiology B: Bio$\log$ 31: 171-177.

Krulko I.V., A.V. Kharina, N.S. Vodzinska, T.O. Filipova and V.P. Polischuk. 2008. Antifitoviral activity of synthetic porphyrins in system in vivo. Ukrainian journal of agroecology. Spec. issue: 138-139. Krulko I.V., S.A. Zaika, A.V. Kharina, N.S. Vodzinska and V.P. Polischuk. 2009. Porphyrins as the inhibitors of viral infection in plant tissue culture. Microbiology \& Biotechnology 2: 47-52.

Kutter Elizabeth and Alexander Sulakvelidze (eds). 2005. Bacteriophages: biology and applications. CRC Press, Boca Raton - London - New York - Washington.

Nitzan Y., H.M. Wexler and S.M. Finegold. 1994. Inactivation of anaerobic bacteria by various photosensitized porphyrins or by hemin. Current Microbiology 29: 125-131.

North J., H. Neyndorff and J.G. Levy. 1993. Photosensitizers as virucidal agents. Journal of Photochemistry and Photobiology B: Biology. 17: 99-108.

Pasternack R.F., E.J. Gibbs and J.J. Villafranca. 1983. Interactions of porphyrins with nucleic acids. Biochemistry 22: 2406-2414.

Philippova T.O., B.N. Galkin, O.Yu. Zinchenko, M.Yu. Rusakova, V.A. Ivanitsa, Z.I. Zhilina, S.V. Vodzinskij and Yu.V. Ishkov. 2003. The antimicrobial properties of new synthetic porphyrins. Journal of Porphyrins and Phthalocyanines 11-12: 737-742.

Ramezani M., J. Behravan, M. Arab and S. Amel Farzad. 2008. Antiviral activity of Euphorbia helioscopia extract. Journal of Biological Sciences 8: 809-813.

Terzaghi, B.E. and W.E. Sandine. 1975. Improved medium for lactic streptococci and their bacteriophages. Applied Microbiology 29: 807-813.

Vodzinska N.S., T.O. Filipova, B.M. Galkin, Yu.V. Ishkov and G.M. Kirichenko. 2008. Staphylococcal bacteriophage inactivation in the presence of synthetic porphyrins. Microbiology \& Biotechnology 3: 82-88.

Zupan K., L. Herenyi, K. Toth, Z. Majer and G.G. Csık. 2004. Binding of cationic porphyrin to isolated and encapsidated viral DNA analyzed by comprehensive spectroscopic methods. Biochemistry 43: 9151-9159. 